\title{
Occurrence and Levels of Organochlorine Pesticide Residues in Maize Samples from Open Markets and Stores in Ile-Ife and Ondo, Southwestern Nigeria
}

\author{
Sosan, M. B., ${ }^{*}$ Oyekunle, J. A. O., ${ }^{2}$ and Odewale, G. O. ${ }^{1}$ \\ ${ }^{1}$ Department of Crop Production and Protection, Obafemi Awolowo University, \\ Ile-Ife, Nigeria \\ ${ }^{2}$ Department of Chemistry, Obafemi Awolowo University, Ile-Ife, Nigeria
}

\begin{abstract}
The levels of organochlorine (OC) pesticide residues in maize grains obtained from open markets and stores in Ile-Ife and Ondo were evaluated and compared with established safety limits. The pretreated samples were Soxhlet extracted and the extracts obtained were analysed for their OCPs content using a Gas Chromatograph coupled with an Electron Capture Detector (GC-ECD). A total of 17 OCPs and their residues were detected in most of the samples with the percentage occurrence ranging between 20 and $100 \%$, and the levels found exceeding their Maximum Residue Limits (MRLs). The mean concentration of $\lambda$-HCH, Endosulfan II and Endrin aldehyde were $0.118,0.592$ and $1.039 \mathrm{mg} \mathrm{kg}^{-1}$, respectively for maize samples obtained from open markets in Ile-Ife. However, maize samples from Ondo had higher levels of Heptachlor epoxide with a mean concentrations of 13.622 and $18.642 \mathrm{mg} \mathrm{kg}^{-1}$ for open markets and stores, respectively. Amounts of OC pesticide residues detected in the maize samples indicated that samples from stores had higher residue levels than those from open markets. The level of OC pesticides contamination of the analysed maize samples portends both short- and long-term public health concerns, calling for regular monitoring of pesticide residues in maize grains and other food items to ensure higher food quality and safety.
\end{abstract}

Keywords: Organochlorine pesticides, maize, residues, market, store.

\section{INTRODUCTION}

Maize, (Zea mays L.) is an important cereal widely cultivated throughout the world in a range of agroecological environments. In Nigeria, maize is mainly produced for local consumption with only small quantities being exported (Cadoni and Angelucci, 2013). The main local dishes produced from maize include pap, tuwo, gwate, and donkunu, with the cereal in cooked, roasted, fried, ground,

*Correspondence email: msosan@oauife.edu.ng pounded or crushed form (Abdulrahaman and Kolawole, 2006). It is also one of the important cereals used in complementary food administered to infants after the age of six months and also serves as the main component of poultry and other livestock feed.

Maize production is constrained by high infestation of insect pests and the maize weevil Sitophilus zeamais Motsch. which is an important field to store insect pest of maize that attacks the grain both in the field and during storage (Adedire, 2001; Sori and Ayana, 2012). 
Worldwide seed losses ranging from 20 to $90 \%$ have been reported for untreated maize due to the maize weevil, S. zemais (De-Lima, 1987; Giga et al., 1991; Boxall, 2002). Synthetic chemical insecticides have been widely used for the control of insect pests of stored grain, particularly S. zeamais (Abebe et al., 2009). However, the application of plant protection chemicals, although, highly necessary and effective, can cause the transfer of hazardous substances into the food chain and also have direct effect on those applying or treating the grains (Lozowicka et al., 2014). Also, maize grains used for feeding livestock may be contaminated and consequently, pesticides may be consumed by humans via animal products. According to Akoto et al. (2013) human exposure to low doses of pesticides through contaminated food may lead to chronic toxicity. Organochlorine pesticides (OCPs) have become universal contaminants found in all segments of the environment and food chain (Alle et al., 2009) and also they are ubiquitous in the environment because of their persistence, bioaccumulation and long-range atmospheric transport (LRAT) (Wang et al., 2009). The accumulation of organochlorine compounds in foods is still a matter of major concern, although, the use of most OCPs have been banned or restricted in most countries. In Nigeria, the use of OCPs have been banned but there is still recent documented evidence of the compounds in food, fish and edible animal tissues, sediments, water and soil samples (Adeboyejo et al., 2011; Oyekunle et al., 2011; Ogah et al., 2012; Ogunfowokan et al., 2012; Olufade et al., 2014; Oyo-Ita et al., 2014; Anzene et al., 2014; Sosan et al., 2015; Tango and Ezemonye, 2015; Shinggu et al., 2015; Oyekunle et al., 2017; Sosan and Oyekunle, 2017). In other parts of the world, OC pesticides have been detected in cereals and grains, such as wheat and maize which are used as raw materials for processing cereal-based complementary foods (Bakore et al., 2004; Mawussi et al., 2009; Akoto et al., 2013; Lozowicka et al., 2014; Mekonen et al., 2015; Akoto et al., 2015).

Systematic and routine monitoring of pesticide residues in agricultural produce is not carried out in Nigeria and there is also a lack of data on the levels of OC pesticides in stored maize in the country despite recent evidences of their residues in some stored food products. The aim of this study was to ascertain the occurrence and consumption safety level of OC pesticide residues in maize grains from selected markets and stores in Ile-Ife and Ondo, southwestern Nigeria.

\section{MATERIALS AND METHODS}

\section{Sample Collection and Preparation}

A total of 20 samples of maize grains consisting of five each from open markets and stores were randomly collected from Ile-Ife and Ondo towns. Maize sample collections were made at the wholesale markets popularly patronized and big stores of maize in both locations. The samples (300 g each) were packed in black polyethylene plastic bags, labelled and transported to the laboratory. Foreign matters, including stones, crumbled shafts and other grains were manually removed from the grains before being dried to a constant weight. Each of the samples was thoroughly ground to powdered form using agate mortar and pestle to ease extraction. Each of the powdered samples was then packed in Ziploc bags, labelled and then stored in a refrigerator at $4{ }^{\circ} \mathrm{C}$ prior to further analysis.

\section{Reagents used and their sources}

The reagents used in this study were dichloromethane (GFS Chemicals, Columbus), n-Hexane (Ultrafine Limited, Marlborough House, London), acetone (GFS Chemicals, Columbus), silica gel 60-200 mesh (Labtech Chemicals), and anhydrous sodium sulphate 
(Merck, Germany). These reagents were procured through various sales representatives of the producing companies' resident in Nigeria. Solvents, such as dichloromethane, nHexane and acetone were doubly distilled using all glass distillation kit to obtain higher purity, while silica gel and anhydrous sodium sulphate were heated in an oven at $120^{\circ} \mathrm{c}$ for $12 \mathrm{~h}$ to ensure that no adsorbed water element remained as part of the clean-up materials.

\section{Extraction Procedure}

Accurately weighed with an electrical digital balance (Model: Mettler Toledo) capable of reading to four decimal places, a $30 \mathrm{~g}$ portion of each ground sample was weighed into a preextracted Whatman extraction thimble. Soxhlet extractor was used following the principle described by Oyekunle et al. (2011). Using 350 $\mathrm{mL}$ of Dichloromethane (DCM) as the extracting solvent, extraction of each sample took an average time of 4 hours. The extract was subjected to distillation for the concentration of the extract to about $4 \mathrm{~mL}$. Further concentration was done to about $2 \mathrm{~mL}$ under a steam of high purity nitrogen. The final extract was kept for clean-up before instrumental analysis.

\section{Clean-up procedure}

A column of about $15 \mathrm{~cm}$ (length) x $1 \mathrm{~cm}$ (internal diameter) was packed first with glass wool and then with about $7.5 \mathrm{~g}$ activated silica gel prepared in a slurry form in DCM. About $5 \mathrm{~g}$ of anhydrous sodium sulphate was placed at the top of the column to absorb any water in the sample or the solvent. Pre-elution was done with $15 \mathrm{~mL}$ of DCM, without exposing the sodium sulphate layer to air, so as to prevent the drying up and cracking of the packed silica gel adsorbent. The reduced extract was run through the column and allowed to sink below the sodium sulphate layer. Elution was done with $3 \times 10 \mathrm{~mL}$ portions of DCM. The eluate was collected and the accompanying solvent was evaporated to dryness under a stream of analytical grade nitrogen (99.99\%). The dried eluate was reconstituted with $1 \mathrm{~mL} 2,2$, 4-trimethylpentane (isooctane) in readiness for instrumental analysis.

\section{Qualitative identification and quantitative evaluation of the $\mathrm{OC}$ pesticides}

The dried eluate was reconstituted with $1 \mathrm{~mL} 2$, 2, 4-trimethylpentane (isooctane). With the aid of a micro syringe, $1 \mu \mathrm{L}$ of the $1.0 \mathrm{~mL}$ purified and reconstituted extract was injected into the injection port of a gas chromatograph coupled with a ${ }^{63} \mathrm{Ni}$ electron capture detector (GC-ECD, Hewlett Packard 5890 series II). The column consisted of a DB-5 fused silica capillary column $(30 \mathrm{~m} \times 0.32$ $\mathrm{mm}$ i.d. $\times 0.25 \mu \mathrm{m}$ film thickness). The temperatures of the injector and detector were $250^{\circ} \mathrm{C}$ and $300^{\circ} \mathrm{C}$, respectively. The injection was carried out on a splitless injector at $200^{\circ} \mathrm{C}$ and the purge activation time was $30 \mathrm{~s}$. The carrier gas was $\mathrm{N}_{2}$ at $30 \mathrm{~mL} / \mathrm{min}$; and the splitless flow rate was $19.6 \mathrm{~mL} / \mathrm{min}$. The run time was 26 minutes. The individual OC pesticides were identified by comparing the elution time of standard OC pesticides with those in the samples, while each OC pesticide was quantified by comparing the peak areas of the OC pesticides in samples with those in the standard. Gas chromatographic analysis of the samples was carried out at the Nigerian Institute of Oceanography and Marine Research (NIOMR) Central Laboratory, Victoria Island, Lagos, Nigeria.

\section{Analyte Residues Analysed}

The samples were analyzed for $\alpha, \beta, \gamma$ and $\delta$-HCH, Aldrin, Dieldrin, Heptachlor, Heptachlor epoxide, Endrin, Endrin aldehyde, Endosulfans, Methoxychlor, DDD, DDE, DDT. The average concentration of OC pesticide 
residues in maize were compared with the MRLs recommended by European Union (2011).

\section{Data analysis and validation of method}

Descriptive statistics (mean, range and standard error) were used to analyze the results obtained using SAS version 9.2 software (SAS Institute, 2003).

\section{Quality Control Measures}

Quality control measures were adopted to ensure that the analytical procedures used complied strictly with appropriate standards and specifications and also to further ensure that the results obtained were reliable, valid and of high quality included the determinations of percentage recovery and detection limit.

\section{Percent recovery $(\% \mathrm{R})$ determination}

Two samples of pulverized maize grains each weighing $20 \mathrm{~g}$ were chosen. One sample was spiked with $10 \mathrm{mg} \mathrm{kg}^{-1}$ standard mixture consisting of some of the available organochlorine pesticides of interest. The mixture was thoroughly mixed together to ensure maximum homogenization. The other sample was left unspiked. The two samples were extracted and further treated following the procedures of Oyekunle et al (2011). Using an injection needle, $1.0 \mu \mathrm{L}$ of the mixture was injected into the GC column for GC-ECD analysis. The recoveries of OCPs were determined by comparing the peak areas of the OCPs after spiking with those of the unspiked and the percentage recovery $(\% \mathrm{R})$ was evaluated based on the expression:

$\% \mathrm{R}=\frac{\text { Peak area of } \mathrm{A}-\text { Peak area of } \mathrm{A}^{\prime}}{\text { Peak area of OC in standard }}$

Where, $\mathrm{A}=\mathrm{OC}$ in spiked sample and $\mathrm{A}^{\prime}=\mathrm{OC}$ in unspiked sample.

\section{Determination of Limit of Detection (LOD)}

The limits of detection (LOD) were evaluated by the determination of concentrations that gave signals equal to the blank signal plus three standard deviations of the blank based on the empirical and more specific definition described by Miller and Miller (2000) using the relationship:

$$
\mathrm{yC}=\mathrm{yB}+3 \mathrm{SB}
$$

where, $\mathrm{yC}=$ analyte signal equivalent to detection limit; $y B=$ blank signal; and $\mathrm{SB}=$ standard deviation of the blank. From the value of $\mathrm{yC}$, the analyte concentration corresponding to the detection limit was evaluated for GC-ECD determination of OC pesticides.

\section{RESULTS}

The percentage recovery $(\% \mathrm{R})$ values of some of the analytes in the maize samples in the range of $89.25 \%$ ( $p, p 2$-DDT) and $98.01 \%$ (Aldrin) are shown in Table 1. The mean concentration of $O C$ pesticide residues in maize samples from open markets in Ile-Ife and Ondo are presented in Table 2. All the isomers of $\mathrm{HCH}$ were detected in all the samples obtained from the two towns except $\alpha-\mathrm{HCH}$ which was the only compound not detected from samples from Ondo. The mean concentration of $\mathrm{HCH}$ residues in maize samples from Ile-Ife ranged from $0.084 \pm 0.034(\beta-\mathrm{HCH})$ to $0.118 \pm 0.072 \mathrm{mg}$ $\mathrm{kg}^{-1}(\gamma-\mathrm{HCH})$, while those of samples from Ondo ranged from $0.064 \pm 0.064(\gamma-\mathrm{HCH})$ to $0.656 \pm 0.655 \mathrm{mg} \mathrm{kg}^{-1}(\beta-\mathrm{HCH})$. The percentage occurrence of the $\mathrm{OC}$ pesticide ranged between 40 and $60 \%$ in Ile-Ife and between 0 [Not Detected (ND)] and 40\% in Ondo.

With the Cylodienes group, mean concentration of $1.039 \pm 0.985,0.913 \pm 0.913$ and $0.827 \pm 0.827 \mathrm{mg} \mathrm{kg}^{-1}$ were recorded for Endrin aldehyde, Heptachlor and Endrin, respectively for 
all maize samples form Ile-Ife with the lowest concentration $\left(0.061 \pm 0.037 \mathrm{mg} \mathrm{kg}^{-1}\right)$ recorded for Aldrin. In Ondo, Dieldrin and Endosulfan sulphate were not detected while Heptachlor epoxide and Endosufan II had mean concentrations of $13.622 \pm 6.067$ and $0.346 \pm 0.288 \mathrm{mg} \mathrm{kg}^{-1}$, respectively. The frequency of occurrence of these pesticides residues ranged from 20 to $40 \%$ and 20 to $60 \%$ in samples from Ile-Ife and Ondo, respectively.

Table 1: Response Factor, Percent Recovery and Limit of Detection for OCPs

\begin{tabular}{llll}
\hline OCPs & RF & \%Recovery & $\begin{array}{l}\text { LOD } \\
(\mu \mathrm{g} / \mathrm{g})\end{array}$ \\
\hline HCB & - & 95.21 & 0.089 \\
Aldrin & 1.439 & 98.01 & 0.029 \\
Dieldrin & 1.092 & 97.27 & 0.068 \\
Heptaclor & 1.345 & 90.09 & 0.086 \\
Endrin & 1.393 & 93.56 & 0.101 \\
$p, p$ ?DDT & 0.958 & 89.25 & 0.081 \\
\hline
\end{tabular}

The observed levels of diphenyls were $0.065 \pm 0.042,0.046 \pm 0.028$ and $0.059 \pm 0.036$ $\mathrm{mg} \mathrm{kg}^{-1}$ for $p$, $p 2$-DDT, $p, p 2$-DDE and $p, p 2$ DDD, respectively in Ile-Ife. However, in Ondo, Methoxychlor had the highest mean concentration of $9.613 \pm 5.930 \mathrm{mg} \mathrm{kg}^{-1}$, followed by DDT $\left(0.392 \pm 0.089 \mathrm{mg} \mathrm{kg}^{-1}\right)$. The percentage occurrence of the different compounds was $40 \%$ for all samples from Ile-Ife and from 40 to $100 \%$ in Ondo. The OC pesticide burden shows that Cyclodiene group had the highest concentrations in Ile-Ife $\left(3.985 \pm 3.848 \mathrm{mg} \mathrm{kg}^{-1}\right)$ and in Ondo $\left(14.708 \pm 6.950 \mathrm{mg} \mathrm{kg}^{-1}\right)$. The levels of all the OC pesticides detected were above the recommended MRL for each of the compounds.

Table 3 shows the levels of OC pesticide residues detected in maize samples from stores in Ile-Ife and Ondo. All the OC pesticides screened were detected in most of the samples from Ile-Ife with the percentage occurrence ranging from 20 to $100 \%$. Among the $\mathrm{HCH}$

Table 2: Mean Concentrations of Organochlorine Pesticide residues in Maize samples from Open markets in Ile-Ife and Ondo, Southwestern Nigeria

\begin{tabular}{|c|c|c|c|c|c|c|c|}
\hline \multirow[b]{2}{*}{ Pesticide } & \multicolumn{3}{|c|}{ Ile-Ife } & & \multicolumn{3}{|c|}{ Ondo } \\
\hline & Mean \pm SE & $\begin{array}{c}\% \\
\text { Occurence }\end{array}$ & $\begin{array}{l}\text { \%above } \\
\text { MRL }\end{array}$ & MRL & Mean \pm SE & $\begin{array}{c}\% \\
\text { Occurence }\end{array}$ & $\begin{array}{c}\% \\
\text { above } \\
\text { MRL }\end{array}$ \\
\hline$\alpha-\mathrm{HCH}$ & $0.114 \pm 0.070$ & 40 & 100 & 0.01 & ND & ND & $\mathrm{ND}$ \\
\hline$\beta-\mathrm{HCH}$ & $0.084 \pm 0.034$ & 60 & 100 & 0.01 & $0.656 \pm 0.655$ & 20 & 100 \\
\hline$\gamma-\mathrm{HCH}$ & $0.118 \pm 0.072$ & 40 & 100 & 0.01 & $0.064 \pm 0.064$ & 20 & 100 \\
\hline$\delta-\mathrm{HCH}$ & $0.087 \pm 0.036$ & 60 & 100 & 0.01 & $0.097 \pm 0.043$ & 40 & 100 \\
\hline$\sum \mathbf{H C H}$ & $0.403 \pm 0.212$ & & & & $0.817 \pm 0.762$ & & \\
\hline Aldrin & $0.061 \pm 0.037$ & 40 & 100 & 0.01 & $0.112 \pm 0.069$ & 40 & 100 \\
\hline Dieldrin & $0.098 \pm 0.098$ & 20 & 100 & 0.01 & ND & ND & ND \\
\hline Endosulfan I & $0.063 \pm 0.063$ & 20 & 100 & 0.05 & $0.009 \pm 0.009$ & 20 & 100 \\
\hline Endosulfan II & $0.592 \pm 0.591$ & 20 & 100 & 0.05 & $0.346 \pm 0.288$ & 40 & 100 \\
\hline $\begin{array}{l}\text { Endosulfan } \\
\text { sulphate }\end{array}$ & $0.329 \pm 0.296$ & 40 & 100 & 0.05 & ND & ND & ND \\
\hline Endrin & $0.827 \pm 0.827$ & 20 & 100 & 0.01 & $0.208 \pm 0.106$ & 60 & 100 \\
\hline Endrin aldehyde & $1.039 \pm 0.985$ & 40 & 100 & 0.01 & $0.127 \pm 0.127$ & 20 & 100 \\
\hline Heptachlor & $0.913 \pm 0.913$ & 20 & 100 & 0.01 & $0.284 \pm 0.284$ & 20 & 100 \\
\hline $\begin{array}{l}\text { Heptachlor } \\
\text { epoxide }\end{array}$ & $0.063 \pm 0.038$ & 40 & 100 & 0.01 & $13.622 \pm 6.067$ & 60 & 100 \\
\hline$\sum$ Cyclodienes & $3.985 \pm 3.848$ & & & & $14.708 \pm 6.950$ & & \\
\hline$p, p$-DDD & $0.059 \pm 0.036$ & 40 & 100 & 0.05 & $0.090 \pm 0.057$ & 40 & 100 \\
\hline$p, p^{\prime}-\mathrm{DDE}$ & $0.046 \pm 0.028$ & 40 & 100 & 0.05 & $0.107 \pm 0.078$ & 40 & 100 \\
\hline$p, p$ '-DDT & $0.065 \pm 0.042$ & 40 & 100 & 0.05 & $0.392 \pm 0.089$ & 100 & 100 \\
\hline Methoxychlor & $0.076 \pm 0.048$ & 40 & 100 & 0.05 & $9.613 \pm 5.930$ & 60 & 100 \\
\hline$\sum$ Diphenyls & $0.246 \pm 0.154$ & & & & $10.202 \pm 6.154$ & & \\
\hline
\end{tabular}

$\mathrm{n}=5$ for each town

ND $=$ Not Detected
$\mathrm{SE}=$ Standard Error of Mean

MRL = Maximum Residue Limit 
Table 3: Mean Concentrations of Organochlorine Pesticide residues in Maize samples from Stores in Ile-Ife and Ondo, Southwestern Nigeria

\begin{tabular}{|c|c|c|c|c|c|c|c|}
\hline & & le-Ife & & & & Ondo & \\
\hline Pesticide & Mean \pm SE & $\begin{array}{l}\% \\
\text { Occu- } \\
\text { rrence }\end{array}$ & $\begin{array}{l}\% \\
\text { above } \\
\text { MRL }\end{array}$ & $\overline{M R L}$ & Mean \pm SE & $\begin{array}{l}\% \\
\text { Occu- } \\
\text { rence }\end{array}$ & $\begin{array}{c}\% \\
\text { above } \\
\text { MRL }\end{array}$ \\
\hline$\alpha-\mathrm{HCH}$ & $0.168 \pm 0.014$ & 100 & 100 & 0.01 & $0.065 \pm 0.065$ & 20 & 100 \\
\hline$\beta-\mathrm{HCH}$ & $0.110 \pm 0.028$ & 80 & 100 & 0.01 & $0.032 \pm 0.032$ & 20 & 100 \\
\hline$\gamma-\mathrm{HCH}$ & $0.130 \pm 0.034$ & 80 & 100 & 0.01 & $0.105 \pm 0.105$ & 20 & 100 \\
\hline$\delta$-HCH & $0.167 \pm 0.017$ & 100 & 100 & 0.01 & ND & ND & ND \\
\hline$\Sigma$ НСН & $0.575 \pm 0.093$ & & & & $0.202 \pm 0.202$ & & \\
\hline Aldrin & $0.120 \pm 0.031$ & 80 & 100 & 0.01 & ND & ND & 100 \\
\hline Dieldrin & $0.310 \pm 0.209$ & 60 & 100 & 0.01 & $0.139 \pm 0.086$ & 40 & 100 \\
\hline Endosulfan I & $0.082 \pm 0.051$ & 40 & 100 & 0.05 & $0.117 \pm 0.117$ & 20 & 100 \\
\hline Endosulfan II & $0.322 \pm 0.165$ & 60 & 100 & 0.05 & $0.091 \pm 0.057$ & 40 & 100 \\
\hline $\begin{array}{l}\text { Endosulfan } \\
\text { sulphate }\end{array}$ & $0.046 \pm 0.046$ & 20 & 100 & 0.05 & $0.080 \pm 0.050$ & 40 & 100 \\
\hline Endrin & ND & ND & ND & 0.01 & $0.250 \pm 0.250$ & 20 & 100 \\
\hline Endrinaldehyde & $0.629 \pm 0.500$ & 60 & 100 & 0.01 & ND & ND & ND \\
\hline Heptachlor & $0.152 \pm 0.072$ & 60 & 100 & 0.01 & $2.151 \pm 2.151$ & 20 & 100 \\
\hline Heptachlor epoxide & $32.647 \pm 32.200$ & 80 & 100 & 0.01 & $18.642 \pm 12.233$ & 40 & 100 \\
\hline$\Sigma$ Cyclodienes & $34.308 \pm 33.274$ & & & & $21.47 \pm 14.944$ & & \\
\hline$p, p$-DDD & $0.102 \pm 0.026$ & 80 & 100 & 0.05 & $0.292 \pm 0.025$ & 100 & 100 \\
\hline$p, p$ '-DDE & $0.186 \pm 0.036$ & 100 & 100 & 0.05 & $0.042 \pm 0.042$ & 20 & 100 \\
\hline$p, p$-DDT & $0.341 \pm 0.175$ & 60 & 100 & 0.05 & $0.031 \pm 0.031$ & 20 & 100 \\
\hline Methoxychlor & $0.108 \pm 0.044$ & 60 & 100 & 0.05 & $21.124 \pm 3.684$ & 100 & 100 \\
\hline$\Sigma$ Diphenyls & $0.737 \pm 0.281$ & & & & $21.489 \pm 4.007$ & & \\
\hline
\end{tabular}

group, was the predominant isomers were $\alpha-\mathrm{HCH}$ and $(\gamma-\mathrm{HCH})$ with a mean concentrations of $0.168 \pm 0.014$ and $0.105 \pm 0.105 \mathrm{mg} \mathrm{kg}^{-1}$ from samples taken from stores in Ile-Ife and Ondo, respectively. However, in the Cyclodienes group, Heptachlor epoxide was the predominant residues in both towns as it occurred at the mean concentration of $32.647 \pm 32.200$ and $18.642 \pm 12.233 \mathrm{mg} \mathrm{kg}^{-1}$ from Ile-Ife and Ondo, respectively. Aldrin and Endrin aldehyde residues had mean concentrations of $0.120 \pm 0.031$ and $0.629 \pm$ $0.500 \mathrm{mg} \mathrm{kg}^{-1}$, respectively from stores in IleIfe, however, these two compounds were detected from maize samples from stores in Ondo. Level of Endrin residues was $0.250 \pm$ $0.250 \mathrm{mg} \mathrm{kg}^{-1}$ in Ondo, but it was not detected in samples in Ile-Ife. High Endosulfan II residues were recorded in Ile-Ife $\left(0.322 \pm 0.165 \mathrm{mg} \mathrm{kg}^{-1}\right)$ and in Ondo $\left(0.091 \pm 0.057 \mathrm{mg} \mathrm{kg}^{-1}\right)$. The levels ofMethoxychlor was excessivelyhigher in samples from Ondo $\left(21.124 \pm 3.684 \mathrm{mg} \mathrm{kg}^{-1}\right)$ compared to Ile-Ife $\left(0.108 \pm 0.044 \mathrm{mg} \mathrm{kg}^{-1}\right)$.

Also, in the samples from Ile-Ife, the concentration of $p, p 2$-DDT was higher $\left(0.341 \pm 0.175 \mathrm{mg} \mathrm{kg}^{-1}\right)$ than its metabolites, $p$, p2-DDD $\left(0.102 \pm 0.026 \mathrm{mg} \mathrm{kg}^{-1}\right)$ and $p$, $p 2-\mathrm{DDE}\left(0.186 \pm 0036 \mathrm{mg} \mathrm{kg}^{-1}\right)$. However, in Ondo, $p, p 2$-DDT had the least detected residue.

The mean concentration of OC pesticides residues detected in maize samples from open markets and stores are presented in Table 4 . The percentage occurrence ranged from 10 to 
Table 4: Mean concentrations of Organochlorine Pesticide residues in Maize samples from Open markets and Stores in Ile-Ife and Ondo, Southwestern Nigeria

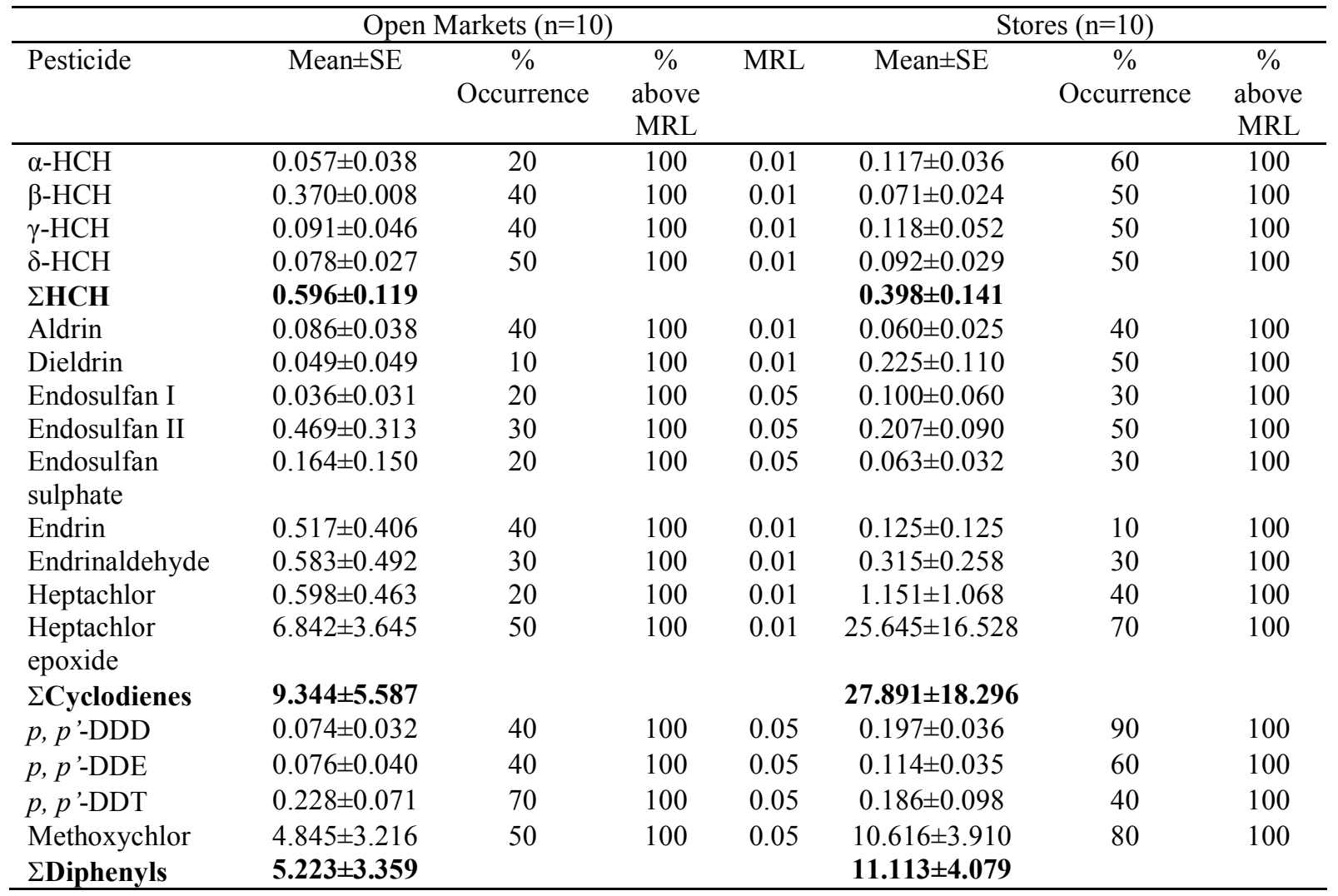

ND $=$ Not Detected

MRL = Maximum Residue Limit

$\mathrm{SE}=$ Standard Error of Mean

$70 \%$ and from 10 to $90 \%$ in open market and in store samples, respectively. The mean concentration of $\gamma-\mathrm{HCH}$ was $0.118 \pm 0.052$ and $0.091 \pm 0.046 \mathrm{mg} \mathrm{kg}^{-1}$ in stores and open market, respectively. The predominant pesticide from the Cyclodienes group was Heptachlor epoxide with very higher residue level of $25.645 \pm$ $16.528 \mathrm{mg} \mathrm{kg}^{-1}$ recorded in the store samples than the open markets samples $(6.842 \pm 3.645$ $\left.\mathrm{mg} \mathrm{kg}^{-1}\right)$. This was followed by Heptachlor $\left(1.151 \pm 1.068 \mathrm{mg} \mathrm{kg}^{-1}\right)$ in samples from stores. Concentration of all other Cyclodienes did not exceed $1 \mathrm{mg} \mathrm{kg}^{-1}$ in both store and open markets samples. Generally, residues of diphenyl compounds were higher in the stores than in open markets, with exception of $p$, $p 2$-DDT. The levels of Methoxychlor were very high in stores $\left(10.616 \pm 3.9100 \mathrm{mg} \mathrm{kg}^{-1}\right)$ than in the open market $(4.484 \pm 3.216 \mathrm{mg}$ $\left.\mathrm{kg}^{-1}\right)$. The least frequently detected pesticides were Endosulfan I $\left(0.036 \pm 0.031 \mathrm{mg} \mathrm{kg}^{-1}\right)$ in open market and Aldrin $\left(0.060 \pm 0.025 \mathrm{mg} \mathrm{kg}^{-}\right.$ $\left.{ }^{1}\right)$ from the stores. All the pesticide residues detected samples were above their respective MRLs.

Figure 1 shows the proportion of OC pesticide burden in maize samples from open markets and stores in Ile-Ife and Ondo. Of the total OC pesticides detected, the percentage burden of $\mathrm{HCH}$ and DDT isomers detected in maize samples from open markets were higher than those from the stores, while the percentage of the 


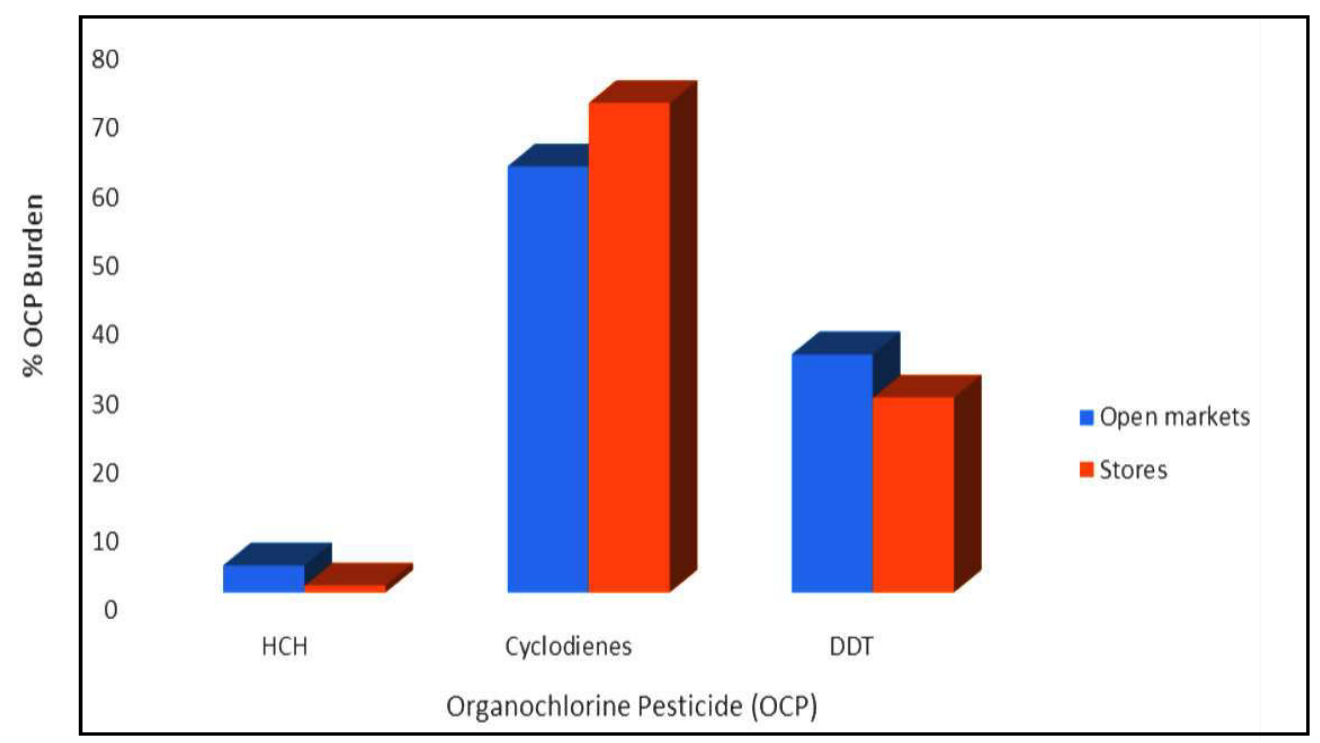

Figure 1: Proportion of Organochlorine pesticide (OCP residues in maize samples from Open Markets and Stores in Ile-Ife and Ondo, Southwestern Nigeria

detected Cyclodienes group of the total OCP was higher in Ondo samples compared to the open markets.

\section{DISCUSSION}

This study established the presence of OC pesticides residues in maize samples from open markets and stores in the selected towns in southwestern Nigeria with percentage occurrence in the samples ranging from 20 to $100 \%$. This observation is similar to the findings of Ogah et al. (2011) who reported that $96 \%$ of the maize samples from Lagos markets contained residues of one or more organochlorine pesticides. The predominance of $\mathrm{HCH}$ isomers in open markets indicated that the OCs were widely used in the protection of the maize against insects. For example, the detection of the $\gamma-\mathrm{HCH}$, the commonly used all-purpose insecticide indicated that this insecticide were still available in the market as this insecticide have been frequently detected in food items in southwestern Nigeria (Adeyeye and Osibanjo, 1999; Ogah et al., 2011; Ogah et al., 2012; Sosan et al., 2015; Sosan and Oyekunle, 2017). The types and frequency of Cyclodienes group of the OCs detected in open markets in Ile-Ife might be due to the high production of maize in the town and its environs and a high demand for the grains by the residents for processing into various local dishes. These factors may have necessitated the high usage of pesticides which resulted in the detection of the compounds in the samples. The predominance and high concentrations of Endosulfans in Ile-Ife also attested to the fact that these compounds are still much in use despite its ban. Olufade et al. (2014) earlier reported the presence of this insecticide in yam chips and cowpea grains in markets in Ile-Ife, while Reksa-Naik and Prasad (2006) stated that endosulfan residues in wheat were reported in all market samples in India. In Cameroon, Sonchieu et al. (2010) reported Lindane and Endosulfan in maize samples with mean concentrations higher than the EU-MRL for the insecticides. However, the detection of high levels of Heptachlor epoxide and Methoxychlor from open markets in Ondo town might be as a 
reflection of the past usage which resulted in bioaccumulation or probably arising from the cultivation of the crop on contaminated soils where application of insecticides were intense. Methoxychlor is a component of DDT. Although, the usage of OC pesticides most especially Lindane $(\gamma-\mathrm{HCH})$ and DDTs in agriculture had been banned in Nigeria but nothing is known about its illegal use through smuggling and possibly through another trade name by which it was being sold in the market. Ondo, a town in Ondo State, is known for high cultivation of cash crops, such as cocoa, which requires large volume of pesticides. This, along with the long establishment of farm settlements in the state, might have been responsible for the detection of high levels of these pesticides in maize samples.

Generally, the results indicated that maize samples from stores contained substantially more OC pesticide residues than those from the open markets. The high rate of occurrence and levels of OC pesticide in store samples most especially in Ile-Ife indicated that more of these chemicals were used for storage of maize. The predominance and high levels of Heptachlor and Heptachlor epoxide from the two towns and Methoxychlor from Ondo further suggest that these compounds must have been active ingredients of common insecticides likely to have been used in the protection of maize against insects in storage. This is likely to happen because most farmers used any available types of insecticide for the control of both the field and storage insect pests. More worrisome is that fact that the agrochemical retailers who the farmers rely upon, to give adequate guidance on various types and proper usage of pesticides are not trained or have limited information on proper handling of pesticides. Hence, they cannot provide adequate guidance to their customers as reported by Sosan et al. (2013). In Ghana, Heptachlor was detected at mean levels of $0.005 \pm 0.005 \mathrm{mg}$ $\mathrm{kg}^{-1}$ in maize while Methoxychlor concentra-tions in maize and cowpea were $0.002 \pm 0.001 \mathrm{mg} \mathrm{kg}^{-}$ ${ }^{1}$ and $0.003 \pm 0.001 \mathrm{mg} \mathrm{kg}^{-1}$ (Akoto et al., 2013). These levels are far lower than what were detected in samples in the present study. Heptachlor, DDT and its metabolites have been detected in rice and wheat from India (Toteja et al., 2003). Also, in India, Bakore et al (2004) reported that all of the wheat samples from India were contaminated with various organochlorine pesticide residues of DDTs and its metabolites, $\mathrm{HCH}$ and its isomers, Heptachlor and its Epoxide and Aldrin.

In a similar study conducted in Turkey, Methoxychlor, DDT and its metabolites, Aldrin, Heptachlor, $\beta$ and $\gamma-\mathrm{HCH}$ were found to be the highest OC pesticide residues in wheat (Guler et al., 2010). Mawussi et al. (2009) also detected $\gamma-\mathrm{HCH}$, Heptachlor, DDT and its metabolites, $\alpha$ and $\beta$-Endosulfan in maize and cowpea in Togo. Aldrin and Dieldrin, the metabolites of Aldrin were reported in maize samples in Korhogo and Sinématiali in Cote D'ivoire (Alle et al., 2009). Also, Mahugija et al. (2017) reported high levels of pesticide residues in maize grains, which are among the sources of poultry feeds in Tanzania.

The Cyclodienes group of the OC pesticides analysed recorded the highest occurrence when compared with $\mathrm{HCH}$ and its isomers or diphenyls. This could be attributed to the ban on Lindane marketed as Gamalin $20 \mathrm{EC}^{\circledR}$ in the $\mathrm{HCH}$ group and DDT which have been only recommended for restricted use for malaria control in some African countries by World Health Organization (WHO). Lozowicka et al (2014) reported that over $60 \%$ of total organochlorine contamination in cereal grains was due to DDTs components in Kazakhstan. In Nigeria, however, there is no official usage of this insecticide. Endosulfan which belongs to the Cyclodienes group is now a popular insecticide available in market which are now been used as a replacement for Lindane. 
Although, Endosulfan has also been banned but they are still available in agrochemical shops in Nigeria.

The residue load above MRL in samples analysed in this study pointed to the fact that there could be illegal use of OC pesticide in the study areas for agricultural purposes either on the field or in storage most especially for protection against maize weevils. The mean concentrations of OC pesticides detected in maize samples from Lagos markets ranged from $7.9-52.0 \mu \mathrm{g} / \mathrm{kg}$ and maximum residue limits (MRLs) of some pesticides were exceeded in up to $7 \%$ of samples (Ogah et al., 2011) while Oyekunle et al (2011) also reported high levels of OC pesticides in top soils of some agricultural farmlands in Oke-Osun farm settlement in Nigeria after many years of their applications. Maximum Residue Limits for $\beta$-HCH, $\beta$-Endosulfan, $p, p$ '-DDE and $p$, $p$ '-DDD were found to be exceeded in both maize and cowpea samples in Ghana (Akoto et al., 2013).

Maize as a major component of livestock feed are only crushed and mixed with other livestock feed ingredients without any further processing for consumption by the birds. According to Udeaan and Bindra (1973) most of the pesticides in cereal grains are contained in outer layers of the grain and therefore, milling and similar processing techniques remove the residues to varied extent. However, the level of concentration and frequency of application of the harmful chemicals may be another factor for consideration in the rate at which processing will reduce the level of pesticide residues. Apart from the regular application of pesticide for protection against field and storage insect pests of maize, the outbreak of occasional insect pests such as armyworm may lead to an increase in application of pesticide which residues could be high in Nigerian staple foods like maize.
According to Zhao et al (2013), Poultry feeds may contain chemical contaminants such as pesticides and can be sources of contamination of poultry products including eggs (Windal et al., 2009). A recent study by Mahugija et al (2018) revealed high levels of OC pesticides, such as Aldrin, Dieldrin, DDT, Endosulfan and $\mathrm{HCH}$ have been reported in poultry feed, raw and cooked eggs with chicken feeds found to be the most contaminated followed by raw eggs and finally cooked eggs.

The occurrence of the OC pesticides above MRLs in the maize samples in the present study is an indication of some form of misuse and/or abuse of these chemicals which may have health implications for both humans and livestock. Although the maize samples from stores contained substantially higher amounts of OC pesticide residues than maize samples from markets, it is, however, not possible to draw conclusions that more of the OC pesticides are being used on maize for storage due to the fact that store owners purchase maize from different locations within the region.

\section{CONCLUSION}

This study revealed that maize samples from open markets and stores in Ile-Ife and Ondo, southwestern Nigeria were contaminated with OC pesticide residues above the Maximum Residue Limits (MRLs). This level of contamination may pose a danger to humans since food contamination is the main route of exposure to OC pesticides. Further monitoring studies on pesticide residues levels of OC pesticides and other pesticides used for maize grain protection in storage and the dietary intakes estimates from the pesticide levels should be evaluated to give an insight into likely health risks to livestock and humans.

\section{REFERENCES}

Abdulrahaman, A. A. and Kolawole, O. M. 
awqist mont zslqmse totsw ganidnitb bns

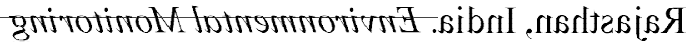
$.08 \varepsilon-18 \varepsilon:(\varepsilon-1) 8 Q$. trigrrzzozza bris

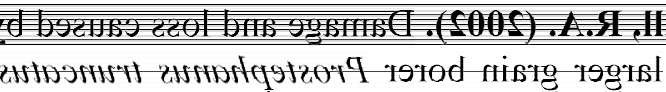

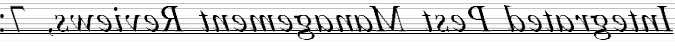
$|s|-60 \mid$

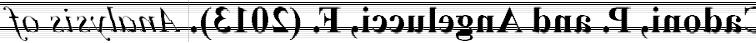

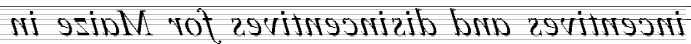

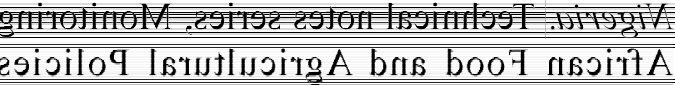

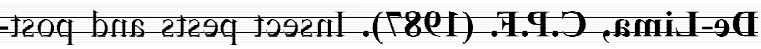

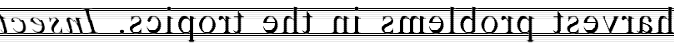

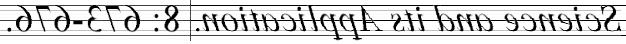

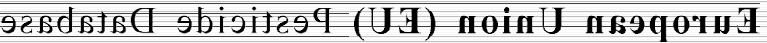

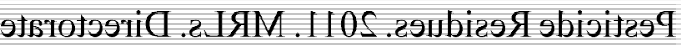

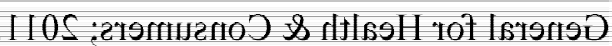

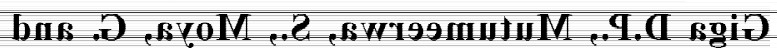

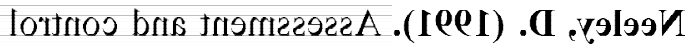

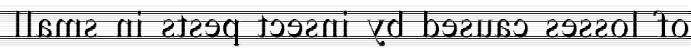

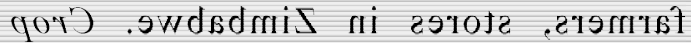
ses- $-58 s: 01$, noitostorit

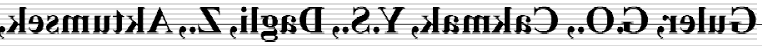

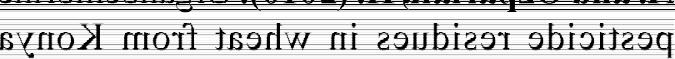

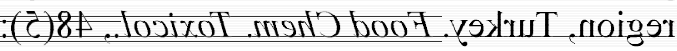
.$I S S I 8 I S I$

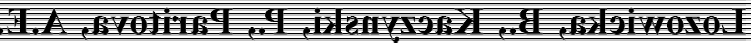

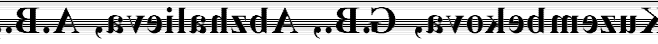

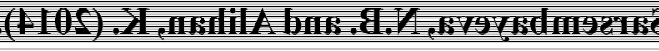

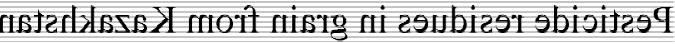

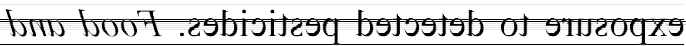

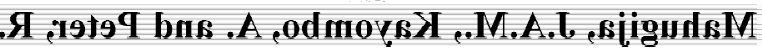

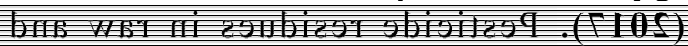
mont rwolt bas anistg 9sism b9azs20t9

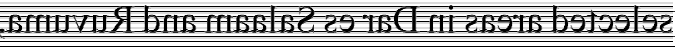

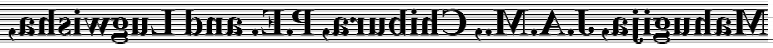

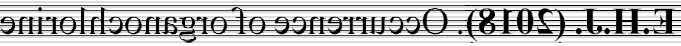

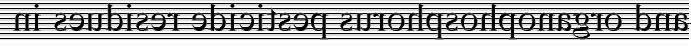

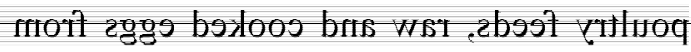

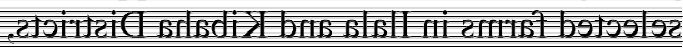

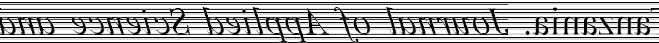
(1)

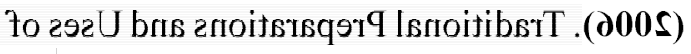

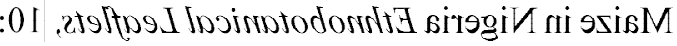
iss-eIs

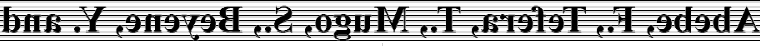

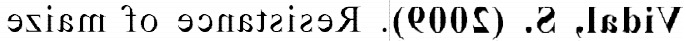

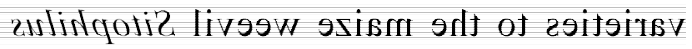

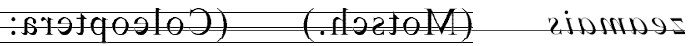
to Inmrusol mboirta (9sbinoiluones .chec-reec:(IS)8:5olombstoid

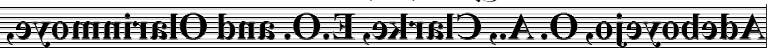

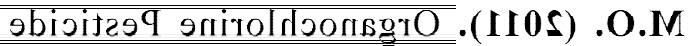

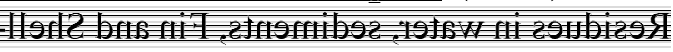

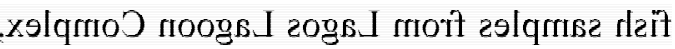

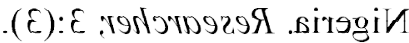
bas voloja . Ygoloig (I00s) .0.5 .97ibshA

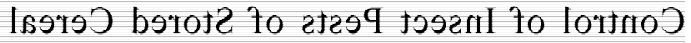

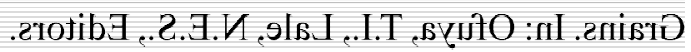

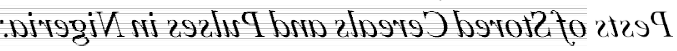

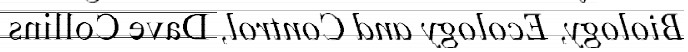
.antoitsoildus

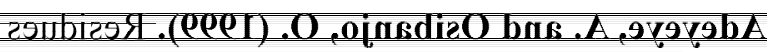

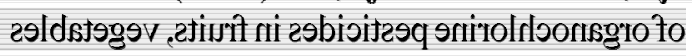

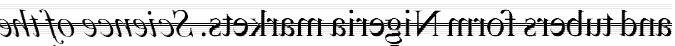

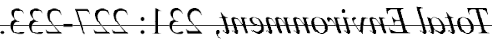

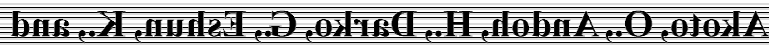

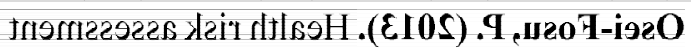
вsqwos bris sxisra nil subizst zsbivitasq to

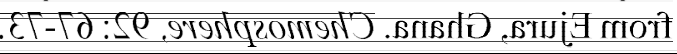

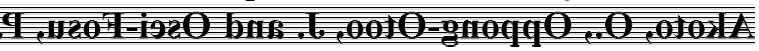

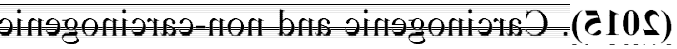

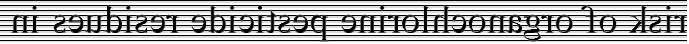

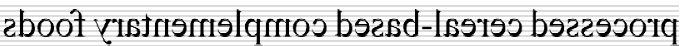

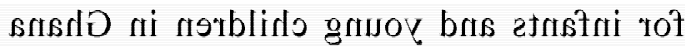

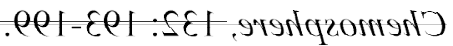

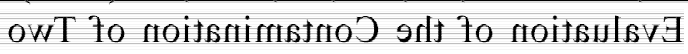
brilqqa to lormol . miovi"a gtôs to djoK

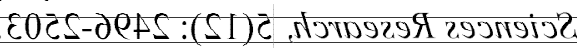

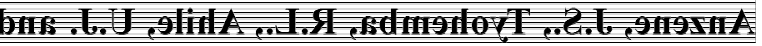
onimolntonsgro .(+10s).A.2.X ,is9ms

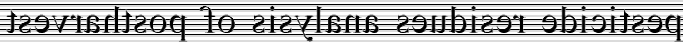

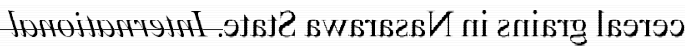

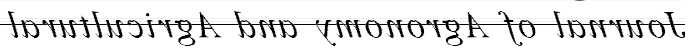

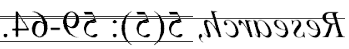

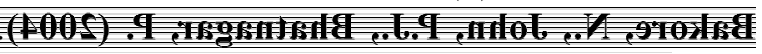

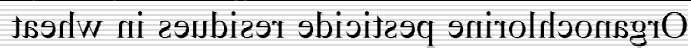


Mawussi, G., Sanda, K., Merlina, G. and Pinelli, E. (2009). Assessment of average exposure to organochlorine pesticides in southern Togo from water, maize (Zea mays) and cowpea (Vigna unguiculata). Food Additives and Contaminants - Part A Chemistry, Analysis, Control, Exposure and Risk Assessment, 26(3): 348-354.

Mekonen, S, Lachat, C., Ambelu, A., Steurbaut, W., Kolsteren, P. Jacxsens, L., Wondafrash, M., Houbraken, M. and Spanoghe, P. (2015). Risk of DDT residue in maize consumed by infants as complementary diet in southwest Ethiopia. Science of the Total Environment, 511: 454460.

Miller J.N. and Miller J.C. (2000). Statistics and Chemometrics for Analytical Chemistry. (4th edn). Pearson Education, 271.

Olufade, Y.A., Sosan, M.B. and Oyekunle, J.A.O. (2014). Levels of organochlorine insecticide residues in cowpea grains and dried yam chips from markets in Ile-Ife, Southwestern Nigeria: A Preliminary Survey. Ife Journal of Science, 16(2): 161-170.

Ogah, C.O., Coker, H.A. and Adepoju-Bello, A.A. (2011). Pesticide residue levels in maize samples from markets in Lagos State, Nigeria. Nigerian Quarterly Journal of Hospital and Medicine, 21(2):169-174.

Ogah, C.O., Tettey, J., Coker, H.B. and AdepojuBello, A.A. (2012). Analysis of organochlorine pesticide residues in beans from markets in Lagos State, Nigeria. West African Journal of Pharmacy. 23(1): 60-68.

Ogunfowokan, A.O., Oyekunle, J.A.O., Torto, N., and Akanni, M.S. (2012). A study on persistent organochlorine pesticide residues in fish tissues and water from an agricultural fish pond. Emirate Journal of Food and Agriculture, 24(2): 165-184.

Oyekunle J.A.O., Ogunfowokan, A.O., Torto, N. and Akanni, M.S. (2011). Determination of organochlorine pesticides in the agricultural soil of Oke-Osun farm settlement, Osogbo, Nigeria. Environmental Monitoring and Assessment, 177: 51-61.
Oyekunle, J.A.O. Akindolani, O.A. Sosan, M.B. and Adekunle A.S. (2017). Organochlorine pesticide residues in dried cocoa beans obtained from cocoa stores at Ondo and Ile-Ife, Southwestern Nigeria. Toxicology Reports, 4: 151-159.

Oyo-Ita, O.E., Ekpo, B.O., Adie, P.A. and Offem J.O. (2014). Organochlorine pesticides in sediment dwelling animals from mangrove areas of the Calabar River, SE Nigeria. Environment and Pollution, 3:3.

Reksa-Naik, S.N. and Prasad, R. (2006). Pesticide residue in organic and conventional food-risk analysis. Chemical Health and Safety, 13: 12-19.

SAS Institute. SAS/STAT Users Guide. Release V9.2. Cary, NC: SAS Institute, 2003.

Shinggu, D.Y., Maitera, O.N., and Barminas, J.T. (2015). Determination of Organochlorine Pesticides Residue in Fish, Water and Sediment in Lake Geriyo Adamawa State Nigeria International Research Journal of Pure and Applied Chemistry, 8(4): 212-220.

Sonchieu, J., Ngassoum, M.B., Tchatchueng, J.B., Srivastava, A.K. and Srivastava, L.P. (2010). Survey of pesticide residues in maize, cowpea and millet from Northern Cameroon: part I. Food Additives and Contaminants, Part B Surveillance, 3: 3, 178-184.

Sori, W. and Ayana, A. (2012). Storage pests of maize and their status in Jimma Zone, Ethiopia. African Journal of Agricultural Research, 7 (28): 4056-4060.

Sosan, M.B., Oni, O. and Folorunso, D.O. (2013). Pesticide handling and associated health risks among agrochemical retailers in Osun State, Nigeria. Ife Journal of Agriculture, 26: 97-110.

Sosan, M.B., Oyekunle, J.A.O. and Olufade, Y.A. (2015). Dichlorodiphenyltrichloroethane (DDT) and Hexachlorohexane $(\mathrm{HCH})$ Pesticide Residues in Foodstuffs from Markets in Ile-Ife, Nigeria. International Journal of Biological and Chemical Sciences, 9(1): 442-453.

Sosan, M. B. and Oyekunle, J. A. O. (2017). Organochlorine Pesticide Residue Levels and 
Potential Human Health Risks in Kolanuts from Selected Markets in Osun State, Southwestern Nigeria. Asian Journal of Chemical Sciences, 2(4): 1-11.

Tango, I and Ezemonye, L. (2015). Human health risks associated with residual pesticide levels in edible tissues of slaughtered cattle in Benin City, Southern Nigeria. Toxicology Reports, 2: 1-19.

Toteja, G.S., Mukherjee, A., Diwakar, S., Singh, P. and Saxena, B.N. (2003). Residues of DDT and $\mathrm{HCH}$ pesticides in rice samples from different geographical regions of India: a multicentre study. Food Additives and Contaminants, 20 (10), 933-939.

Udeaan., A.S. and Bindra, O.S. (1973). Malathion residues in different fractions of treated food grains and their finished derivatives. In: Bindra, O.S., Kalra, R.L. (eds.), Progress and problems in pesticide residue analysis.
Punjab Agricultural University and Indian Council of Agricultural Research, Ludhiana, pp. 61-67.

Wang, X., Ren, N., Qi, H., Ma, W. and Li, Y. (2009). Levels, distributions, and source identification of organochlorine pesticides in the topsoils in Northeastern China. Journal of Environmental Sciences, 21: 1386-1392.

Windal, I., Hanot, V., Marchi, J., Huysmans, G., Van Overmeire, I., Waegeneers, N. and Goeyens, L. (2009). PCB and organochlorine pesticides in home-produced eggs in Belgium. Science of the Total Environment. 407: 4430-4437.

Zhao, L., Dong, Y.H., and Wang, H. (2013). Residues of organochlorine pesticides and Polycyclic aromatic hydrocarbons in farmraised livestock feeds and manures in Jiangsu, China. Science of the Total Environment, 450451: 348-355.

Nigeria Journal of Entomology

Published by the Entomological Society of Nigeria

www.esnjournal.com.ng

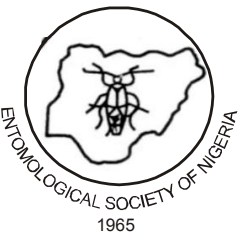

ISSN: 0331-0094

Vol. 34, 2018; pp. 25-37

DOI: $10.36108 / \mathrm{NJE} / 8102 / 43(0140)$ 